Article

\title{
Sub-National Institutional Contingencies and Corporate Social Responsibility Performance: Evidence from China
}

\author{
Shahid Ali ${ }^{1}{ }^{\mathbb{D}}$, Junrui Zhang ${ }^{1}$, Muhammad Usman ${ }^{2,3}, *$, Farman Ullah Khan ${ }^{1}$, Amir Ikram ${ }^{4}$ and \\ Bilal Anwar 5 (D) \\ 1 School of Management, Xi'an Jiaotong University, Xi'an 710049, China; shahidali24@hotmail.com (S.A.); \\ zhangjr@mail.xjtu.edu.cn (J.Z.); farman.sikandry@gmail.com (F.U.K.) \\ 2 Division of Computational Mathematics and Engineering, Institute for Computational Science, \\ Ton Duc Thang University, Ho Chi Minh City 700000, Vietnam \\ 3 Faculty of Finance and Banking, Ton Duc Thang University, Ho Chi Minh City 700000, Vietnam \\ 4 Institute of Business \& Management, University of Engineering \& Technology, Lahore 54000, Pakistan; \\ amirikram12@hotmail.com \\ 5 Department of Management Sciences, Bahria University Lahore Campus, Lahore 54000, Pakistan; \\ bilal.bulc@bahria.edu.pk \\ * Correspondence: usman@tdtu.edu.vn
}

Received: 24 July 2019; Accepted: 24 September 2019; Published: 2 October 2019

\begin{abstract}
This study investigates the relationship between sub-national institutional contingencies and corporate social responsibility performance (CSRP). Sub-national institutional contingencies (SNICs) play a moderating role in the link between CSRP and corporate financial performance (CFP). Using data from all A-share Chinese companies listed on the Shenzhen and Shanghai exchanges for the period 2010 to 2015, ordinary least square (OLS) regression was used as a baseline methodology to draw inferences from the data. The study uses propensity score matching (PSM) to confirm the robustness and to tackle the possible issue of endogeneity. We find reliable evidence that SNICs have a positive and significant effect on CSRP. This positive relationship is more pronounced in cross-listed companies as compared to state-owned enterprises (SOEs) and in companies located in the more developed region. Moreover, SNICs moderate the positive relationship between CSRP and CFP. The relationship is stronger in firms that are non-SOEs, are non-cross-listed, and are from less-developed regions as compared to their counterparts. The findings provide implications for regulators and individual companies. Investment in corporate social responsibility (CSR) helps companies to achieve their primary objective (i.e., financial performance). With respect to practical implications, the study indicates that policymakers, executives, and managers should refrain from "one size fits all" CSR policies. Instead, they need to simultaneously evaluate the effects of regional development, cross-listing, and ownership characteristics. Considering weak social performance by firms that are from less developed regions, are non-cross-listed, and that are non-SOEs, policymakers and the government should improve information transparency and the regulatory framework, and provide these firms with incentives. This study also provides insights for other emerging economies, especially those going through extraordinary government interventions.
\end{abstract}

Keywords: subnational institutional contingencies (SNICs); corporate social responsibility performance; corporate financial performance; institutional theory; China 


\section{Introduction}

Corporate social responsibility (CSR) is gaining vital importance in today's dynamic business world. The World Business Council for Sustainable Development considered CSR as an essential element of sustainable economic development and welfare of society [1]. CSR practices are also necessary for legitimizing the actions of an organization [2], enhancing the company's image [3], and obtaining financial benefits [4]. Although financial performance remains the primary motive of every firm $[5,6]$, stakeholders' expectations for firms to behave in socially responsible ways have become a growing concern [5-7]. For instance, investors may raise social issues along with financial performance [8], reflecting their apprehension with respect to the triple bottom line of social, environmental, and economic performance [5]. Moreover, social scholars also suggest that strategies and operational decision of firms should ally with their economic, social, and environmental elements $[9,10]$, and thus firms can gain a sustained competitive advantage by the induction of the triple bottom line of business [11,12].

There are vast differences in perceptions of CSR among different countries' institutional environments that can be traced back to institutional pressure [13], regulations and government policies, or unique political traditions about companies' social responsibility [14]. There can also be a crucial difference in understanding and practice of CSR across industries within national institutional contexts [15]. Kang and Moon [16] analyzed three models of capitalism to check the influence of national institutional arrangement on CSR. Firstly, there are the liberal market economies, for example those of the United States and the United Kingdom, where managers are sensitive to the demands of shareholders and seek to enhance firm performance through CSR, while investors and governments favor market-based solutions to pursue CSR. Secondly, there are coordinated market economies like those of Japan and Germany, where the firm's management is more focused on the demands of a broader range of stakeholders using non-market based techniques. Thirdly, there are state-led market economies like those of South Korea, France, and China, where the government can resolve social issues by encouraging firms to be more socially responsible and through the introduction of coercive regulations (e.g., mandatory CSR reporting).

The concept of CSR may also vary among industries depending on their nature and institutional settings [17]. Institutional factors in corporate governance research have received very little attention. Few studies focus on institutional drivers of CSR with respect to resource-based theory and agency theory, stakeholder theory, and legitimacy theory, while some studies examine CSR in a cross-country setting [11-13,18-23]. The studies suggest that institutional factors and pressure such as government regulations, the legal system, national culture, and corporate governance significantly influence the firm's CSR policies. However, the institutional pressure put on firms is not homogenous due to many factors such as political resources [24], public policies [25], Guanxi (relationship) [26,27], a high level of government involvement [26,27], geographical remoteness [28], and formal and informal institutional environments $[28,29]$.

The mechanism through which corporate social responsibility performance (CSRP) is influenced by institutional settings is monitoring. Market competition is the most influential monitoring mechanism [30], for which a transparent CSR contract plays a crucial role (37). Mutual monitoring executed by more than one executive can mitigate the agency problem [31,32], and it can effectively substitute other governance mechanisms. External Chief Executive officer (CEO hereafter) incentives have a significant effect on policy choices and firm risk [33]. Li et al. [34] advocated that the risk-adjusted level of debt is a better determinant of corporate conservatism. For better institutional monitoring, Core and Guay [35] suggested that firms should set optimal equity incentive levels for CEOs and grant new equity incentives.

Given the growing importance of monitoring mechanisms, institutional contingencies within an economy become quite an interesting topic to be explored. Subnational institutional contingencies mean different characteristics of various institutional settings within the same country. We studied the most relevant aspects of sub-national institutional contingencies in the Chinese economy i.e., ownership 
pattern (state vs. non-state ownership), regional diversities (developed region vs. less-developed region), and the listing pattern of companies in stock exchanges (cross-listed vs. non-cross listed). Literature suggests that subnational institutional varies in complex and large emerging economies [36]. We selected China as a focal region because it offers a diverse ownership structure [37], it has a number of subnational regions [38], and because some Chinese firms also chose to cross-list in Hong Kong by issue share (H-share) [39]. Such variations enable us to explore how formal and informal institutional contexts affect corporate social responsibility performance (CSRP). These formal and informal instructional contexts are considered sub-national institutional contingencies [40].

Considering the importance of countries' institutional settings by recent scholars, the following question arises: How do institutional variations within-country influence corporate social responsibility and the nexus between corporate social responsibility and firm financial performance? After identifying this gap, we have endeavored to make four contributions to the literature by analyzing this important but underexplored question. First, we investigate whether different sub-national institutional contingencies have a different relationship with corporate social responsibility performance. Our study suggests that sub-national institutional differences are most significant in constraining and facilitating strategic choices (CSR policies/activities) in the largest emerging economies. Second, we explore the relationship between corporate social responsibility performance and corporate financial performance. Our study findings reveal that the firm's CSR is not only concerned with stakeholders demands but also enhances a firm's financial position by creating the firm's image in the eyes of society, government, and media, etc. Third, we contribute to the emerging literature by demonstrating the CSR effect on a firm's financial performance by focusing on its sub-national institutional contingencies. This study put forward that CSR activities positively influence the firms' financial performance, but this relationship is stronger for firms that are non-state-owned enterprises (non-SOEs), are non-cross-listed, and are from less developed regions as compared to their counterparts. The possible reason for this relationship is the higher pressure and scrutiny on firms that are SOEs, are cross-listed, and that are from developed regions by the dominant stakeholder; thus, they are legally bound to pursue social practices in addition to improving their financial performance. Fourth, we extend the literature beyond developed countries by providing one of the first empirical study from the world's largest emerging economy, China. We consider unique Chinese institutional factors for investigating this study, because institutional factors play a significant role in corporate strategic options in emerging economies; in addition, the most promising corporate governance research focuses on understanding institutional factors [41].

\section{Institutional Background}

Institutions are defined as "humanly devised constraints that structure human interaction" [42]. Institutional factors function as informal and formal "rules of the game" to socially constrain organizational practices [42]. Socially sanctioned norms embedded in ideology and culture are called informal institutions, which are maintained through reenactment in self-enforcing in nature and behavior [43]. The developed and established paths in firms for policies, firm structure, strategies, and practices represent the institutional environment [44]. In short, firms are influenced by both informal norms and formal rules. Institutional pressure derives firms from implementing internal practices consistent with informal norms and formal regulations [45]. The Shenzhen and Shanghai stock exchanges are two major stock exchanges in China. The China Securities Regulatory Commission (CSRC) performs a unified regulatory function according to relevant regulations and laws with authority by state council over futures and security markets of China. Issuance of specific rules and regulations relevant to the Chinese stock market is one of the supervisory duties of the CSRC.

According to Deng Xiaoping, the "chief architect" of the reform policy, regional diversity has replaced inter-regional equality, and this has expanded over time [28]. To attain more equity among regions, programs such "Go West", "Rising of China", and "Rebounding of Northeast old industry base" were launched in 2000, 2003, and 2004, respectively. These programs led to developing particular urban areas rather than the balanced development of entire regions. Economic decentralization has 
increased economic decision-making of local governments in areas with respect to resolving business disputes, urban development plans, and the provision of public goods locally. The effect of government intervention is magnified by poor local government quality [28,46]. State-owned enterprises (SOEs) allocate more resources to local government due to their stock rights as well as to attain more regional economic growth [47]. In addition, SOEs issue publicly traded debt, equity, and secure bank loans $[28,46]$. According to Filatotchev and Nakajima [48], non-state-owned enterprises (non-SOEs) choose CSR based on cost-benefit analysis instead of agency costs and institutional pressures.

Regarding CSR, former President Hu Jintao declared the goal of building a harmonious society [28]. This was a signal that China would endeavor to realize balanced economic development, and would be committed to confronting environmental and social concerns [24]. In the year 2006, an SOE, namely, the State Grid Corporation, became the first Chinese company to publish their CSR report. Subsequently, regulatory agencies, e.g., the Shenzhen and Shanghai stock exchanges, the China Securities Regulatory Commission, and local government agencies issued recommendations and guidelines to encourage environmental and corporate social practices. In 2008, the Shanghai stock exchange issued an announcement about strengthening performance of listed companies with respect to social responsibility. Consequently, the number of CSR reports increased from 471 to 701 in the period of 2009 to 2014, at an annual growth rate of $8.14 \%^{2}$.

\section{Literature Review}

Institutional theory suggests that companies are prejudiced by pressure in their institutional environment for conformity, compliance, and constraining organizational actions applied through their referent spectators. According to Moratis [49], enterprises prioritize different practices, including environmental and social activities that are mostly influenced by the institutional system in which they operate. In fact, CSR is defined as "those lines of action which are desirable in term of the objectives and value of a society" [50]. In particular, when companies design their CSR strategies, they need to understand various forms of institutional logic [18-20]. The logic brings concurrent pressures, as companies must consider socially accepted rules and expectations of various stakeholders. There are mixed findings related to the CFP-CSRP relationship. For example, Li et al. [51] endorsed that corporate social performance has positive and significant relationship with earnings. Using the Resource-Based View, Mellahi et al. [21] found a positive association between CSR and financial performance. They also propose that CSR activities are marginally detrimental in the short run, but constructive to companies' financial performance in the long-term [52].

However, there may be a countervailing effect between cost and benefits. Based on the argument, CSR benefits offset its costs and there is positive implications of CSR on CFP [53-55]. On the other hand, the empirical studies also suggested the negative association between firm's CSR and financial performance [56,57], since investment in social projects might undermine the primary objective of the company and results in additional costs, which can ultimately destroy shareholders' value. Busch and Friede [58] emphasized the importance of CSR and argued that it is difficult to replicate the intangible character of corporate reputation that leads to sustainable financial benefits. Though previous studies found that there is overwhelming evidence of a significant and positive relationship between CSR and the firm's financial performance [58-60], the literature on the CSRP-CFP nexus is inconclusive, especially in emerging markets like that of China. Based on the aforementioned arguments, we have formulated several hypotheses.

Hypothesis 1. Corporate social responsibility performance is positively associated with corporate financial performance.

According to Rettab and Mellahi [61], CSR drivers such as government, community pressure, customers, and non-governmental organizations that push the organizations to behave in a socially responsible manner are still weak in emerging markets. The neo-institutional theory states that different 
organizations in various countries have different CSR priorities because of cultural elements, e.g., organizational actions, socially accepted rules, and beliefs [29]. Previous studies advocates that the geographical spread of firms play an essential role in voluntary CSR initiatives, e.g., [49,62].

The ownership structure is unique in China [63]. The distinguishing feature of Chinese listed firms is that the majority of the listed firms are owned and controlled by the local or central government. The Chinese government supports state-owned enterprises (SOEs) with substantial means endowments $[46,47,64,65]$. Recently, the government privatized several state-owned enterprises during economic reforms. However, as compared to non-SOEs, these firms still maintain sufficient state shares to retain voting control and to exert more political influence over these firms $[66,67]$. As a result, board members and executives of SOEs are strongly inclined towards making a firm decision on behalf of government interest, involving different objectives, i.e., social objectives apart from financial gains $[68,69]$.

The government agencies always monitor CEO performance in SOEs. The government provides sufficient financial support to SOEs [64,65], motivating executives to engage in social welfare [70]. The Chinese government also offers more subsidies to the state executives [71], and thus persuades them to participate in social activities [72]. Zheng and Zhang [73] reported that SOEs are more substantial than their counterparts, which often perform better in CSR. However, a few studies found that the government sometimes tolerates irresponsible behavior of SOEs because they provide fewer incentives to implement CSR or due to some other economic goals $[28,74,75]$. Non-SOEs are founded by entrepreneurs or returnee entrepreneurs in China [76]. Therefore, as compared to SOEs, non-SOEs tend to behave more strategically, leading to differences in operational, competitive, and corporate strategies. Based on their financial goals, Non-SOEs choose strategic CSR based on cost-benefit analysis rather than institutional pressure [48]. Previous studies highlighted that SOEs outperform non-SOEs in CSR activities. As Liu and Zhang [77] pointed out, the goal of SOEs is not only earning a profit, but also to providing public goods and employment and maintaining social stability.

The ownership structure across countries affect the relationship between stakeholders of a company [78]. The most potent stakeholder (the government) facilitates SOEs during financial distress for their CSR involvement [72,73], and thus CSR leads to better financial performance of firms [58]. However, Li et al. [79] found that the link of CSRP-CFP is weaker in SOEs as compared with non-SOEs, and highlighted several reasons for this discrepancy. First, the objective of SOEs includes social aims along with economic goals. Second, regardless of profitability SOEs need to legitimize their position and are likely to perform in CSR. Third, executives of SOEs are evaluated by government agencies frequently, and their promotion might depend on the review, where social orientation is also considered. SOEs do CSR due to regulation pressure, while non-SOEs do CSR based on their financial goals. Following this logical reasoning, we hypothesize:

Hypothesis 2. SOEs are more socially responsible than non-SOEs.

Hypothesis 3. The positive relationship between CSRP and CFP is weaker in SOEs than in non-SOEs.

The institutional pressure for cross-listed firms is also considerable and it affect a firm's strategic orientation. According to Shi et al. [80], there are two ways of cross-listing of Chinese firms in the Hong Kong stock exchange. First, there is back-door listing (e.g., taking over a firm listed in Hong Kong). Second, there is direct listing of mainland firms into the Hong Kong stock exchange and issue share (H-share). Cross-listed firms are influenced by different social norms and regulatory regimes, that accelerate their CSR investment as compared to their counterparts [80-83]. Similarly, Shi et al. [80] demonstrated that other dimensions of CSR performance (e.g., technical CSR) improve with the cross-listing because of sophisticated systems for securities supervision and the stringent regulations on information disclosure. This was also claimed in [84]. Cross-listing organizations links them to a legal, strict regulatory and well-reputed environment, where insiders have fewer incentives to invest in CSR. This negative view of CSR reduces the firms' CSR likelihood after cross-listing [82]. 
CSR can be used as a tool for risk management to mitigate litigation risk [85]. Hong and Liskovich [86] stated that CSR could help against unfavorable regulation through a halo effect, "whereby one's judgment of another character influenced by one's overall (and usually first) impression". Boubakri et al. [82] encountered the same results. Cross-listed firms need to conform socially constructed values, beliefs, and the system of norms to attain legitimacy in foreign stock markets [83]. Moreover, these firms are more open to regulatory and legal standards and shareholder protection $[40,84]$ and thus enjoy a premium in domestic firms [87]. Through a meta-analysis, del Mar Miras-Rodríguez et al. [88] analyzed the moderating role of national culture on the CSR-firm performance (FP) nexus and found that national culture affects the CSR and FP relationship. The cross-listed firms are somehow bound to perform well in CSR while the domestic firms are not under such obligation. However, they do CSR to achieve financial goals, and they care more about cost-benefit analysis rather than institutional pressures [48]. We thus expect that cross-listed firms are more greatly associated with CSRP, and the positive association of CSRP-CFP is weaker in cross-listed than in non-cross-listed firms, which leads to the following hypothesis.

Hypothesis 4. Cross-listed firms are more greatly associated with CSRP than non-cross-listed firms.

Hypothesis 5. The positive association between CSRP and CFP is weaker in cross-listed than in non-cross-listed firms.

Firms located in different regions have a heterogeneous institutional environment [89]. The market development process or the "marketization" level has achieved different growth level among provinces [90]. Typically, central and western provinces are less developed than eastern coastal areas in term of per capita foreign investment, Gross Domestic Product (GDP), and so on [91]. Along with unbalanced economic growth, informal and formal institutional contexts are also different in various regions of China. As Tse [39] reported that Chinese provinces often "retain their distinct identities, with their cuisines, customs, dialects, and sometimes languages". According to Shi et al. [37], there is a difference among these regions based on property rights protection, contract enforcement, and market monitoring mechanisms. CSR engagements are pronounced in firms located near to the headquarters and cities (developed regions) [92], due to the visibility and media exposure [93,94].

Developed regions provide potential support in obtaining CSR information, i.e., law, accounting, and media [94,95]. According to Tang et al. [28] the firm's geographical location is vital for corporate social performance in China; SOEs located in urban areas witnessed higher social interest than firms located in rural areas due to information asymmetry, media coverage, etc. Informal and formal "rules of the game" vary by geography $[29,30]$. Moreover, companies of urban regions are more developed and more bound to perform in socially responsible ways [28,30], while companies' social participation in less-developed regions relies on slack resources [28,29].

A developed region has sufficient civil rights and property rights protection for creditors and investors, while less-developed regions face less rigorous law enforcement, more exploitation, more business intervention, and less effective local-governments [40,96]. CEOs in the less developed regions face less effective internal and external monitoring, and therefore they take advantage of exclusive benefits from a dominant position [97]. The previous literature suggests that CEOs invest in CSR in order to reap benefits such as image building and provide more incentives with the increase in financial performance. Executives tend to overinvest in CSR for their own benefit as well, as a good reputation increases bargaining power and outside career opportunities [98]. Busch and Friede [58] emphasized CSR importance and argued that it is difficult to replicate the intangible character of corporate reputation that leads to sustainable financial benefits. However, based on these arguments, we expect a positive relationship between developed regions and CSRP. Therefore, we formulate the following hypothesis. 
Hypothesis 6. Firms from developed regions are more strongly associated with CSRP than firms from less-developed regions.

Hypothesis 7. The positive association between CSRP and CFP is weaker in firms from developed regions than in firms from less-developed regions.

\section{Sample, Variables, Descriptive Statistics, and Methodology}

\subsection{Data Source and Sample}

The study uses China's stock market and a reliable data source (China Stock Market \& Accounting Research, CSMAR) to collect data for the proposed variables. CSR rating data were obtained from Ranking (RKS), which is an independent standardized agency established in 2007 that provides independent ratings of Chinese listed firms [99]. These reputed and reliable databases in China are not publicly available, but we deployed institutional relationships to get access to these databases. The initial sample consists of all A-share and H-share companies listed on the Shanghai, Shenzhen, and Hong Kong Stock exchanges from 2010 to 2015. We choose 2010 as starting year for the sample because after the global financial crisis of 2008, China's financial environment experienced significant changes, and many listed firms in China obtained CSR ratings at the beginning of year 2010. Firm-year observations with missing values of the study variables were removed from the sample as per practices of the previous literature. The final useable sample entailed 11,991 firm-year observations.

\subsection{Variable Measurement}

CSRP is used both as a dependent and independent variable in this study. Following the previous studies $[24,38,99,100]$, the study considers social rating score issued by Ranking (RKS) based on the Global Reporting Initiative (GRI 3.0). For the CSR rating score, the RKS review and CSR reports based on three main dimensions (overall evaluation, technical evaluation, and content evaluation) further cover 70 sub-dimensions of CSR activities. The average scores assigned to these three dimensions have different weights, i.e., 30\%, 20\%, and, 50\%, representing the composite CSR rating score for a particular firm. A validity test of the measure was done with satisfactory results by the previous researchers $[24,101]$. The CSR rating score ranges from 0 to 100; higher rating reflects better CSR performance [102].

Sub-national institutional contingencies used as an independent and a moderating variable. In line with previous studies $[37,40,87,91,96]$, we measure sub-national institutional contingencies as SOE vs. non-SOE, cross-listed vs. non-cross-listed, and developed regions vs. less-developed regions. For SOE, the dummy variable equals 1 if the state or central government is the controlling owner and 0 if it is a non-SOE. For cross-listed firms, the dummy variable equals 1 if the firm is also listed on the Hong Kong stock exchange and 0 if it is non-cross-listed. To explore whether the CSR varies across firms located in more developed and less developed regions, for regional development (R_Dev), the dummy variable equals 1 if the firm's head office located in more developed regions of China, and 0 otherwise.

Consistent with literature [98,103-110], several firm-related characteristics (i.e., ownership structure, board structure, and economic characteristics) were used as control variables in this study. Board shareholding (B_Share) was calculated as the percentage of shares held by the board of directors. Using the board structure variable, we control for board size, board independence, and CEO duality. Board size (B_Size) means the total number of directors on the board. The proportion of independent/outside directors is called board independence (Ind_Dir). For CEO duality (CEO_Duality), the dummy variable equals 1 if the $\mathrm{CEO}$ is also the chairperson, and 0 otherwise. This study also controls for economic characteristics, including firm size, firm age, growth opportunity, firm's market performance, firm growth, and financial leverage. Firm size (Size) is defined as the natural log of total sales. Firm age (F_Age) is the total number of years since the firm was first listed on the stock 
exchange. Growth opportunity (BTMA) is calculated as the book-to-market ratio. The market value of the firm (TobinQ) is calculated as the market value of assets divided by book values of assets [102]. Firm growth (Growth) describes the change in the total assets of a company. Financial leverage (F_Lev) is calculated as the ratio of total debt to total assets. For more details, see Table 1.

Table 1. Description of variables. CSR: corporate social responsibility; SOE: state-owned enterprise.

\begin{tabular}{|c|c|}
\hline Variables & Description \\
\hline CSR_Rating & CSR rating score is weighted average ranging from 0 to 100 issued by Rankings (RKS). \\
\hline SOE (state-owned enterprise) & $\begin{array}{l}\text { A dummy variable that equals } 1 \text { if the state or central government is the controlling owner and } 0 \\
\text { if it is a non-SOE. }\end{array}$ \\
\hline Cross-listed & $\begin{array}{l}\text { A dummy variable that equals } 1 \text { if the firm is cross-listed Hong Kong Stock Exchange and } 0 \text { if it } \\
\text { is non-cross-listed. }\end{array}$ \\
\hline R_Dev (regional development) & $\begin{array}{l}\text { A dummy variable that equals } 1 \text { if the firm's head office is located in more developed regions of } \\
\text { China, and } 0 \text { otherwise. }\end{array}$ \\
\hline B_Size & The number of directors on the board. \\
\hline Ind_Dir & The proportion of independent/outside directors on the board. \\
\hline CEO duality & A dummy variable that equals 1 if the CEO is working as a chairperson and otherwise 0 . \\
\hline B_Share & The percentage of shares held by a firm board of directors. \\
\hline Size & The log of total sales. \\
\hline Growth & Change in firms total assets. \\
\hline F_Lev & The ratio of total debt to the total asset. \\
\hline F_Age & The number of years the firm has been listed on the stock exchange. \\
\hline TobinQ & The industry-adjusted Tobin's Q ratio. \\
\hline BTMA & The book-to-market ratio. A ratio of a publicly traded company's book value to its market value. \\
\hline
\end{tabular}

\subsection{Descriptive Statistics and Correlation Matrix}

The descriptive statistics reported in Table 2 for all the variables. The results depict that the mean of CSRP is 28.71, with a standard deviation of 19.439. This indicates that firms on average achieve 28.71 percent composite CSR score in China, with a maximum rating out of 90.84 . The average firm board size is 10.27, with 38 percent having independent directors in China. The ratio of independent directors should be one-third of the total directors onboard, as per the requirements of China Regulatory Commission (CSRS); this study reflects the same.

Table 2. Descriptive statistics.

\begin{tabular}{ccccc}
\hline Variable & Mean & Standard Deviation & Min & Max \\
\hline CSR_Rating & 28.71 & 19.44 & 0 & 90.84 \\
SOE & 0.46 & 0.50 & 0 & 1 \\
Cross-listed & 0.03 & 0.18 & 0 & 1 \\
R_Dev & 0.25 & 0.43 & 0 & 1 \\
B_Size & 10.27 & 2.64 & 5 & 27 \\
Ind_Dir & 0.38 & 0.07 & 0.17 & 0.8 \\
CEO duality & 0.25 & 0.43 & 0 & 1 \\
B_Share & 0.1 & 0.18 & 0 & 0.89 \\
Size & 3.06 & 0.07 & 2.20 & 3.36 \\
Growth & 0.71 & 2.08 & -45.72 & 64.69 \\
F_Leverage & 0.55 & 2.37 & -0.19 & 142.72 \\
F_Age & 10.19 & 6.35 & 0 & 26 \\
TobinQ & 5.40 & 372.16 & 0.03 & $50,939.53$ \\
BTMA & 0.92 & 1.07 & 0 & 36.72 \\
\hline
\end{tabular}


Table 3 portrays the average CSR performance of companies considering sub-national institutional contingencies in China. The average CSR rating obtained by Chinese SOEs is 31.7, while the performance of non-SOEs is 26.06, showing that SOEs tend to participate more in social activities. Similarly, cross-listed firms obtained a higher average for their CSR practices as compared to than non-cross-listed firms, (49.68, and 27.95, respectively). The companies with a head office in a developed region lead as compared to their counterparts, with an average of 30.02 and with a maximum CSR performance of 90.32 .

Table 3. Sub-sample of companies' average CSR performance.

\begin{tabular}{cccccc}
\hline Sub Sample & $\boldsymbol{N}$ & Mean & Std. Dev. & Min & Max \\
\hline STATE $=1$ & 5051 & 31.73 & 21.75 & -13.05 & 90.83 \\
STATE $=0$ & 5758 & 26.06 & 16.72 & -15.20 & 90.32 \\
Cross-Listed $=1$ & 367 & 49.68 & 23.20 & -8.33 & 90.25 \\
Cross-Listed $=0$ & 10,419 & 27.95 & 18.86 & -15.20 & 90.84 \\
R_Dev $=1$ & 4815 & 30.02 & 19.37 & -15.20 & 89.12 \\
R_Dev $=0$ & 5994 & 27.66 & 19.44 & -13.95 & 90.32 \\
\hline
\end{tabular}

Note: STATE $=1$ denotes sample of firms having large state ownership and 0 otherwise. Cross-listed $=1$ considers only those firms cross-listed on Hong Kong stock exchange and 0 otherwise. R_Dev $=1$ includes firms located in developed regions and 0 otherwise.

The correlations matrix between variables is reported in Table 4 . The correlation between CSR rating and SOEs is 0.15 , and is positively significant. The correlation between cross-listed firms and CSR is also significant and positive, and the same relationship observed for R_Dev and CSR ratings. The results are consistent with the previous literature. The correlations among other all variables are within the executable limits. 
Table 4. Pairwise correlations.

\begin{tabular}{|c|c|c|c|c|c|c|c|c|c|c|c|c|c|c|c|}
\hline Variables & 1 & 2 & 3 & 4 & 5 & 6 & 7 & 8 & 9 & 10 & 11 & 12 & 13 & 14 & 15 \\
\hline 1. CSR_rating & 1.00 & & & & & & & & & & & & & & \\
\hline 2. $\mathrm{SOE}$ & $0.15 *$ & 1.00 & & & & & & & & & & & & & \\
\hline 3. Cross-listed & $0.20 *$ & $0.15 *$ & 1.00 & & & & & & & & & & & & \\
\hline 4. R_Dev & $0.06 *$ & $-0.15^{*}$ & $0.04 *$ & 1.00 & & & & & & & & & & & \\
\hline 5. B_Size & $0.05 *$ & $0.22 *$ & $0.11 *$ & $-0.04^{*}$ & 1.00 & & & & & & & & & & \\
\hline 6. Ind_Dir & 0.01 & $-0.10 *$ & $0.03 *$ & $0.02 *$ & $-0.08^{*}$ & 1.00 & & & & & & & & & \\
\hline 7. CEO duality & $-0.08 *$ & $-0.30 *$ & $-0.05 *$ & $0.09 *$ & $-0.10 *$ & $0.07 *$ & 1.00 & & & & & & & & \\
\hline 8. SOE & $0.15^{*}$ & $1.00 *$ & $0.15^{*}$ & $-0.15^{*}$ & $0.22 *$ & $-0.10 *$ & $-0.29 *$ & 1.00 & & & & & & & \\
\hline 9. B_Share & $-0.07^{*}$ & $-0.49 *$ & $-0.09 *$ & $0.14 *$ & $-0.17^{*}$ & $0.11^{*}$ & 0.26 * & $-0.49 *$ & 1.00 & & & & & & \\
\hline 10. Size & $0.36^{*}$ & $0.35 *$ & $0.31^{*}$ & 0.01 & $0.21 *$ & $0.02 *$ & $-0.16^{*}$ & $0.35 *$ & $-0.26^{*}$ & 1.00 & & & & & \\
\hline 11. Growth & $0.03 *$ & $-0.05 *$ & $-0.02 *$ & -0.00 & $0.05^{*}$ & -0.01 & $0.05 *$ & $-0.05^{*}$ & $0.06^{*}$ & 0.02 & 1.00 & & & & \\
\hline 12. F_Leverage & $-0.03 *$ & 0.00 & 0.00 & $-0.03 *$ & $0.07^{*}$ & -0.01 & $-0.04^{*}$ & 0.00 & $-0.15^{*}$ & 0.11 * & $-0.12 *$ & 1.00 & & & \\
\hline 13. F_Age & $0.03 *$ & $0.39 *$ & $0.02 *$ & $-0.15^{*}$ & $0.14 *$ & $-0.06^{*}$ & $-0.22 *$ & $0.39 *$ & $-0.55^{*}$ & $0.19 *$ & $-0.05^{*}$ & $0.07 *$ & 1.00 & & \\
\hline 14. TobinQ & $-0.03 *$ & -0.01 & -0.00 & -0.01 & $-0.03 *$ & 0.01 & 0.00 & -0.01 & 0.01 & $-0.12 *$ & $0.02 *$ & $0.57 *$ & 0.00 & 1.00 & \\
\hline 15. BTMA & $0.17^{*}$ & $0.26^{*}$ & $0.15 *$ & $-0.02 *$ & $0.12 *$ & -0.01 & $-0.11^{*}$ & 0.26 * & $-0.24 *$ & $0.51^{*}$ & $-0.02 *$ & 0.03 * & $0.21 *$ & -0.01 & 1.00 \\
\hline
\end{tabular}
$*, * * * * *$, significant at $10 \%, 5 \%$, and $1 \%$, respectively. $t$-statistics are reported in parentheses. For a detailed description of variables, see Table 1 . 


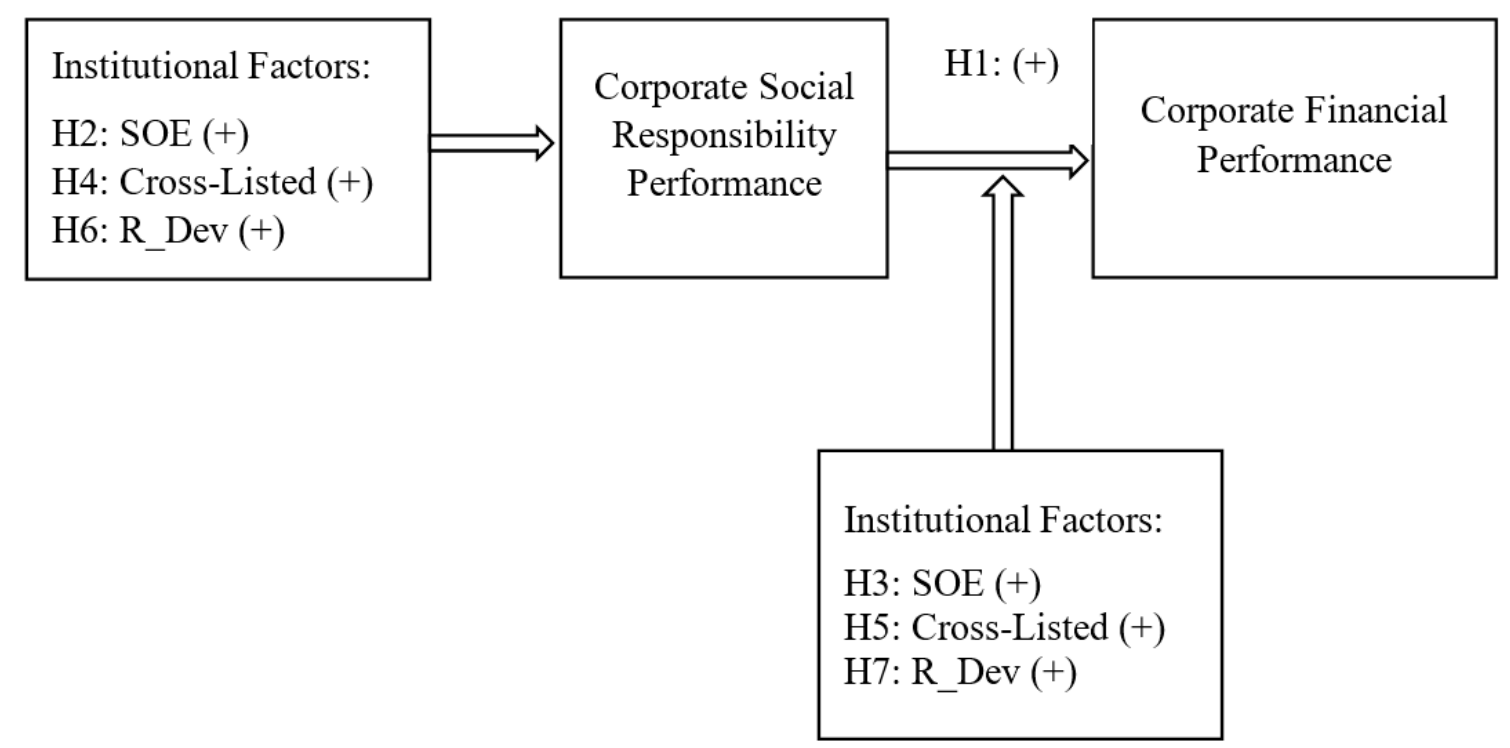

Figure 1. Subnational institution-based view of corporate social responsibility performance.

\subsection{Empirical Model}

Following the previous literature $[4,88,98,101]$, we used ordinary least square (OLS) regression to estimate the effect of subnational institutional contingencies on CSR, and test the relationship between CSR and CFP. We also test the moderating role of SNICs between the CSR and CFP nexus.

$$
\begin{aligned}
& \operatorname{CFP}_{\text {it }}=\alpha+\beta_{1} \operatorname{CSRP}_{i t}+\sum_{i=1}^{n} \beta_{n} \text { Controls }_{i t}+\varepsilon_{i t} \\
& \operatorname{CSRP}_{i t}=\alpha+\beta_{1} \text { SNIC }_{i t}+\sum_{i=1}^{n} \beta_{n} \text { Controls }_{i t}+\varepsilon_{i t}
\end{aligned}
$$

where subscript $i$ is the firm, $t$ is time, and CSRP indicates corporate social responsibility performance scaled by RKS ratings. CFP refers to measures of the corporate firm performance (e.g., TobinQ). SNICs refer to subnational institutional contingencies (e.g., SOE vs. non-SOE, cross-listed vs. non-cross-listed, R_Dev vs. less-R_Dev) Controls refers to all control variables (B_Size, Ind_Dir, CEO duality, B_Share, Size, Growth, F_Leverage, F_Age, TobinQ, and BTMA). To control for year and industry fixed effect this study includes year and industry dummies at the two-digit SIC level. For a detailed description of the variables, see Table 1.

\section{Results and Discussion}

Table 5 reports regression results for SNICs and CSRP along with the moderating role of SNICs in CSRP and CFP nexus. Figure 1 represents the regression results graphically. In Table 5, Models 1-4 show the direct effect of SNICs (e.g., SOE vs. non-SOE, cross-listed vs. non-cross-listed, R_Dev vs. less-R_Dev) on the CSRP. Model 5 reports the results for the association between CSRP and CFP; the coefficient is positive and significant at $p<0.01$ that confirms Hypothesis 1 . Model 1 demonstrates the results for SOE impact on CSRP in which the coefficient value $(0.97 p<0.05)$ shows that the relationship is significant and positive, confirming our Hypothesis 2. Similarly, Hypothesis 4 and 6 are also confirmed by Model 2 and 3 that report the results for cross-listing and R_Dev, and indicate that the coefficients of cross-listing $(\beta=8.93, p<0.01)$ and $R_{-} \operatorname{Dev}(\beta=0.91, p<0.05)$ are significant and positive in both models. In Model 4, we applied the regression with all SNICs and found the 
positive and significant relationship with CSRP as consistent with previous models. In Model 6, we also include all SNIC variables as a control variable to confirm their positive relationship with CSR, and coefficient remains consistent.

Table 5. Main regression.

\begin{tabular}{|c|c|c|c|c|c|c|}
\hline \multirow[b]{2}{*}{ Performance } & \multicolumn{4}{|c|}{$\begin{array}{c}\text { Subnational Institutional Contingencies and CSR } \\
\text { Performance }\end{array}$} & \multicolumn{2}{|c|}{ CSR and Performance } \\
\hline & Model 1 & Model 2 & Model 3 & Model 4 & Model 5 & Model 6 \\
\hline CSR_Rating & $\longrightarrow$ & & & - & $\begin{array}{c}0.06^{* * *} \\
(4.85)\end{array}$ & $\begin{array}{c}0.06^{* * *} \\
(4.55)\end{array}$ \\
\hline SOE & $\begin{array}{l}0.97^{* *} \\
(2.24)\end{array}$ & & & $\begin{array}{c}0.871^{* *} \\
(2.01)\end{array}$ & & $\begin{array}{l}0.13^{* *} \\
(2.21)\end{array}$ \\
\hline Cross-listed & & $\begin{array}{c}8.93^{* * *} \\
(9.22)\end{array}$ & & $\begin{array}{c}8.80 * * * \\
(9.07)\end{array}$ & & $\begin{array}{l}4.03^{* * *} \\
(2.99)\end{array}$ \\
\hline R_Dev & & & $\begin{array}{l}0.91^{* *} \\
(2.39)\end{array}$ & $\begin{array}{l}0.75^{* *} \\
(1.96)\end{array}$ & & $\begin{array}{c}0.25^{* * *} \\
(2.47)\end{array}$ \\
\hline B_Size & $\begin{array}{l}-0.12 \text { * } \\
(-1.75)\end{array}$ & $\begin{array}{l}-0.13 \text { ** } \\
(-2.01)\end{array}$ & $\begin{array}{l}-0.12 \text { * } \\
(-1.73)\end{array}$ & $\begin{array}{l}-0.13^{* *} \\
(-1.99)\end{array}$ & $\begin{array}{l}-0.20 * * \\
(-2.24)\end{array}$ & $\begin{array}{l}-0.21^{*} \\
(-2.32)\end{array}$ \\
\hline Ind_Dir & $\begin{array}{l}5.80 * * \\
(2.49)\end{array}$ & $\begin{array}{l}5.11^{* *} \\
(2.20)\end{array}$ & $\begin{array}{l}5.89^{* *} \\
(2.53)\end{array}$ & $\begin{array}{l}5.20^{* *} \\
(2.24)\end{array}$ & $\begin{array}{l}3.50 * * \\
(1.99)\end{array}$ & $\begin{array}{l}3.24^{* *} \\
(1.89)\end{array}$ \\
\hline CEO duality & $\begin{array}{l}-0.35 \\
(-0.87)\end{array}$ & $\begin{array}{l}-0.45 \\
(-1.10)\end{array}$ & $\begin{array}{l}-0.40 \\
(-0.99)\end{array}$ & $\begin{array}{l}-0.49 \\
(-1.20)\end{array}$ & $\begin{array}{l}-1.27^{*} \\
(-2.28)\end{array}$ & $\begin{array}{l}-1.32 * * \\
(-2.35)\end{array}$ \\
\hline B_Share & $\begin{array}{c}3.18^{* * *} \\
(2.72)\end{array}$ & $\begin{array}{c}3.22 * * * \\
(2.77)\end{array}$ & $\begin{array}{l}2.98^{* *} \\
(2.54)\end{array}$ & $\begin{array}{c}3.05^{* * *} \\
(2.61)\end{array}$ & $\begin{array}{l}-2.32 \\
(-1.44)\end{array}$ & $\begin{array}{c}2.30 \\
(-1.42)\end{array}$ \\
\hline Size & $\begin{array}{c}124.77^{* * * *} \\
(42.08)\end{array}$ & $\begin{array}{c}118.06^{* * * *} \\
(38.90)\end{array}$ & $\begin{array}{c}123.82^{* * * *} \\
(41.41)\end{array}$ & $\begin{array}{c}117.37^{* * * *} \\
(38.42)\end{array}$ & $\begin{array}{c}-59.71^{* * *} \\
(-13.67)\end{array}$ & $\begin{array}{c}-62.44^{* * *} \\
(-13.96)\end{array}$ \\
\hline Growth & $\begin{array}{c}0.05 \\
(0.60)\end{array}$ & $\begin{array}{c}0.09 \\
(1.03)\end{array}$ & $\begin{array}{c}0.06 \\
(0.68)\end{array}$ & $\begin{array}{c}0.10 \\
(1.09)\end{array}$ & $\begin{array}{l}1.51 * * * \\
(12.42)\end{array}$ & $\begin{array}{l}1.52^{* * *} \\
(12.53)\end{array}$ \\
\hline F_Leverage & $\begin{array}{c}-2.26^{* * *} \\
(-7.21)\end{array}$ & $\begin{array}{c}-2.24^{* * *} \\
(-7.16)\end{array}$ & $\begin{array}{c}-2.25^{* * *} \\
(-7.18)\end{array}$ & $\begin{array}{c}-2.23^{* * *} \\
(-7.13)\end{array}$ & $\begin{array}{c}13.02^{* * *} \\
(31.43)\end{array}$ & $\begin{array}{c}13.01^{* * *} \\
(31.39)\end{array}$ \\
\hline F_Age & $\begin{array}{l}-0.11^{* * *} \\
(-3.10)\end{array}$ & $\begin{array}{c}-0.09 * * * \\
(-2.63)\end{array}$ & $\begin{array}{l}-0.11^{* * *} \\
(-2.98)\end{array}$ & $\begin{array}{l}-0.09 * * \\
(-2.55)\end{array}$ & $\begin{array}{c}-0.06 \\
(-1.23)\end{array}$ & $\begin{array}{c}-0.05 \\
(-1.03)\end{array}$ \\
\hline TobinQ & $\begin{array}{c}0.03^{* * *} \\
(4.85)\end{array}$ & $\begin{array}{c}0.03^{* * *} \\
(4.56)\end{array}$ & $\begin{array}{c}0.03^{* * *} \\
(4.84)\end{array}$ & $\begin{array}{c}0.03^{* * *} \\
(4.55)\end{array}$ & - & - \\
\hline BTMA & $\begin{array}{c}-1.63^{* * *} \\
(-7.40)\end{array}$ & $\begin{array}{c}-1.68^{* * *} \\
(-7.67)\end{array}$ & $\begin{array}{c}-1.59 * * * \\
(-7.21)\end{array}$ & $\begin{array}{l}-1.65^{* * *} \\
(-7.50)\end{array}$ & $\begin{array}{l}-0.14 \\
(-0.47)\end{array}$ & $\begin{array}{c}-0.16 \\
(-0.54)\end{array}$ \\
\hline Constants & $\begin{array}{c}-355.71^{* * *} \\
(-39.58)\end{array}$ & $\begin{array}{c}-335.05^{* * *} \\
(-36.40)\end{array}$ & $\begin{array}{c}353.10 * * * \\
(-39.01)\end{array}$ & $\begin{array}{c}-333.18^{* * *} \\
(-36.00)\end{array}$ & $\begin{array}{c}178.05^{* * *} \\
(13.56)\end{array}$ & $\begin{array}{c}186.45^{* * *} \\
(13.87)\end{array}$ \\
\hline Year dummies & Included & Included & Included & Included & Included & Included \\
\hline $\begin{array}{l}\text { Industry dummies } \\
\qquad \mathrm{R}^{2}\end{array}$ & $\begin{array}{c}\text { Included } \\
0.243\end{array}$ & $\begin{array}{c}\text { Included } \\
0.249\end{array}$ & $\begin{array}{c}\text { Included } \\
0.243\end{array}$ & $\begin{array}{l}\text { Included } \\
0.249\end{array}$ & $\begin{array}{c}\text { Included } \\
0.118\end{array}$ & $\begin{array}{c}\text { Included } \\
0.119\end{array}$ \\
\hline
\end{tabular}

$*, * * * * *$, significant at $10 \%, 5 \%$, and $1 \%$, respectively. $t$-statistics are reported in parentheses. For a detailed description of variables, see Table 1 .

We took a step further in analysis to test whether SNICs moderate the link between CSRP and CFP. The study analyzes the moderating role of SNICs on an individual basis. In Model 1 of Table 6, we test the role of SOEs in the CSRP-CFP nexus, while in Model 2, non-SOEs are considered. The coefficient in both models is significant and positive. However, the value of the coefficient is higher in non-SOEs, which indicates that the relationship between CSRP and CFP is more prominent in non-SOEs as compared to their counterparts, as Hypothesis 3 predicts. The government persuades the SOEs to participate in social activities [72], while non-SOEs choose strategic CSR based on cost-benefit analysis rather than institutional pressures [48]. 
Table 6. The moderating role of SNIC: nexus between corporate social responsibility performance (CSRP) and corporate financial performance (CFP).

\begin{tabular}{|c|c|c|c|c|c|c|}
\hline \multirow[b]{2}{*}{ Performance } & \multirow{2}{*}{$\begin{array}{c}\text { SOE } \\
\text { Model } 1\end{array}$} & \multirow{2}{*}{$\begin{array}{c}\text { Non-SOE } \\
\text { Model } 2\end{array}$} & \multirow{2}{*}{$\begin{array}{c}\text { Cross-Listed } \\
\text { Model } 3\end{array}$} & \multicolumn{2}{|c|}{ Non-Cross-Listed R_Dev } & \multirow{2}{*}{$\begin{array}{c}\text { Less-R_Dev } \\
\text { Model } 6\end{array}$} \\
\hline & & & & Model 4 & Model 5 & \\
\hline CSR_Rating & $\begin{array}{l}0.01 * * * \\
(7.30)\end{array}$ & $\begin{array}{l}0.08^{* * *} \\
(2.96)\end{array}$ & $\begin{array}{c}0.01^{*} \\
(1.64)\end{array}$ & $\begin{array}{l}0.06^{* * *} \\
(4.61)\end{array}$ & $\begin{array}{c}0.01^{* * *} \\
(6.88)\end{array}$ & $\begin{array}{l}0.17^{* * *} \\
(8.45)\end{array}$ \\
\hline SOE & 1.001 & & $\begin{array}{c}0.02 \\
(0.14)\end{array}$ & $\begin{array}{c}0.14 \\
(0.23)\end{array}$ & $\begin{array}{l}0.19^{* *} \\
(2.37)\end{array}$ & $\begin{array}{c}0.88 \\
(1.01)\end{array}$ \\
\hline Cross-listed & $\begin{array}{c}0.60^{* * *} \\
(6.61)\end{array}$ & $\begin{array}{c}6.72 \\
(1.34)\end{array}$ & & & $\begin{array}{c}0.61^{* * *} \\
(3.80)\end{array}$ & $\begin{array}{c}3.87^{*} \\
(1.77)\end{array}$ \\
\hline R_Dev & $\begin{array}{l}0.11^{* *} \\
(2.23)\end{array}$ & $\begin{array}{l}-0.29 \\
(-0.28)\end{array}$ & $\begin{array}{c}0.11 \\
(0.92)\end{array}$ & $\begin{array}{c}0.20 \\
(0.37)\end{array}$ & & \\
\hline B_Size & $\begin{array}{c}0.00 \\
(0.25)\end{array}$ & $\begin{array}{c}-0.49^{* * * *} \\
(-2.66)\end{array}$ & $\begin{array}{c}0.02 \\
(1.37)\end{array}$ & $\begin{array}{l}-0.23^{* *} \\
(-2.38)\end{array}$ & $\begin{array}{c}0.02 \\
(1.38)\end{array}$ & $\begin{array}{l}-0.29 * * \\
(-2.23)\end{array}$ \\
\hline Ind_Dir & $\begin{array}{l}0.77^{* * * *} \\
(2.60)\end{array}$ & $\begin{array}{c}2.11 \\
(0.36)\end{array}$ & $\begin{array}{c}0.79 \\
(1.33)\end{array}$ & $\begin{array}{c}3.20 \\
(0.96)\end{array}$ & $\begin{array}{l}0.75^{*} \\
(1.86)\end{array}$ & $\begin{array}{c}2.72 \\
(0.56)\end{array}$ \\
\hline CEO duality & $\begin{array}{l}-0.15^{* *} \\
(-2.28)\end{array}$ & $\begin{array}{l}-2.07^{* *} \\
(-2.29)\end{array}$ & $\begin{array}{c}0.12 \\
(0.81)\end{array}$ & $\begin{array}{l}-1.36^{* *} \\
(-2.35)\end{array}$ & $\begin{array}{l}0.13^{* *} \\
(1.97)\end{array}$ & $\begin{array}{l}-2.34 \\
(-2.67)\end{array}$ \\
\hline B_Share & $\begin{array}{l}5.98^{* * *} \\
(5.21)\end{array}$ & $\begin{array}{l}-4.18^{*} \\
(-1.76)\end{array}$ & $\begin{array}{l}-0.18 \\
(-0.19)\end{array}$ & $\begin{array}{l}-2.29 \\
(-1.39)\end{array}$ & $\begin{array}{c}0.23 \\
(1.23)\end{array}$ & $\begin{array}{c}0.29 \\
(0.11)\end{array}$ \\
\hline Size & $\begin{array}{l}-12.41^{* * *} \\
(-29.52)\end{array}$ & $\begin{array}{c}-97.60 * * * \\
(-11.71)\end{array}$ & $\begin{array}{c}-5.61^{* * *} \\
(-6.92)\end{array}$ & $\begin{array}{c}-64.63 * * * \\
(-13.85)\end{array}$ & $\begin{array}{c}-11.74^{* * *} \\
(-20.09)\end{array}$ & $\begin{array}{c}-92.99 * * * \\
(-14.30)\end{array}$ \\
\hline Growth & $\begin{array}{c}-0.01 \\
(-0.84)\end{array}$ & $\begin{array}{l}2.63^{* * *} \\
(12.03)\end{array}$ & $\begin{array}{l}0.17^{* *} \\
(2.37)\end{array}$ & $\begin{array}{l}1.54^{* * *} \\
(12.39)\end{array}$ & $\begin{array}{c}-0.10^{* * *} \\
(-5.55)\end{array}$ & $\begin{array}{l}1.72 * * * \\
(10.28)\end{array}$ \\
\hline F_Leverage & $\begin{array}{c}0.60^{* * *} \\
(6.90)\end{array}$ & $\begin{array}{c}14.21 * * * \\
(24.08)\end{array}$ & $\begin{array}{l}-0.82 * * \\
(-2.31)\end{array}$ & $\begin{array}{c}13.04^{* * *} \\
(30.88)\end{array}$ & $\begin{array}{l}1.07^{* * *} \\
(27.46)\end{array}$ & $\begin{array}{l}60.97^{* * *} \\
(58.25)\end{array}$ \\
\hline F_Age & $\begin{array}{c}0.00 \\
(0.58)\end{array}$ & $\begin{array}{l}-0.05 \\
(-0.58)\end{array}$ & $\begin{array}{l}0.02 * \\
(1.79)\end{array}$ & $\begin{array}{c}-0.04 \\
(-0.82)\end{array}$ & $\begin{array}{l}0.01^{*} \\
(1.76)\end{array}$ & $\begin{array}{c}-0.44^{* * *} \\
(-6.13)\end{array}$ \\
\hline BTMA & $\begin{array}{l}-0.33^{* * *} \\
(-14.16)\end{array}$ & $\begin{array}{c}0.55 \\
(0.66)\end{array}$ & $\begin{array}{l}-0.10^{* *} \\
(-2.26)\end{array}$ & $\begin{array}{l}-0.16 \\
(-0.47)\end{array}$ & $\begin{array}{l}-0.57^{* * *} \\
(-14.03)\end{array}$ & $\begin{array}{c}-3.31 * * * \\
(-7.38)\end{array}$ \\
\hline Constants & $\begin{array}{c}39.59^{* * *} \\
(31.40)\end{array}$ & $\begin{array}{c}295.22 * * * \\
(11.76)\end{array}$ & $\begin{array}{c}19.48^{* * *} \\
(7.79)\end{array}$ & $\begin{array}{c}193.14^{* * *} \\
(13.76)\end{array}$ & $\begin{array}{c}37.44^{* * *} \\
(21.08)\end{array}$ & $\begin{array}{c}259.65^{* * *} \\
(13.29)\end{array}$ \\
\hline Year dummies & Included & Included & Included & Included & Included & Included \\
\hline Industry dummies & Included & Included & Included & Included & Included & Included \\
\hline$R^{2}$ & 0.405 & 0.142 & 0.516 & 0.119 & 0.381 & 0.401 \\
\hline
\end{tabular}

$* * * * * *$, significant at $10 \%, 5 \%$, and $1 \%$, respectively. $t$-statistics are reported in parentheses. For a detailed description of variables, see Table 1 .

Model 3 and 4 report the results for the moderating role of cross-listed and non-cross-listed firms, respectively. The value of the coefficient is significant and positive in both cases, but the relationship is more robust in non-cross-listed firms, which endorses Hypothesis 5 of the study. According to Liu [84], sophisticated systems for securities supervision, and the stringent regulations pressurize cross-listed companies for CSR information disclosure, while non-cross-listed companies involve in CSR for their own benefits. The results for R_Dev and less-R_Dev are reported in Model 5 and 6 of Table 6. The findings support Hypothesis 7 and suggest that the CSRP-CFP nexus is more noticeable in less-developed regions than in more developed regions, because companies located in developed regions are bound to perform well in social activities [28,30], while companies in less-developed regions invest in CSR based on resource constraints [28,29].

Some control variables are worth mentioning. The board structure variables B_Size, B_Share, and Ind_Dir remain significant in this study. The coefficient of B_Size is negative and significant, showing that the larger board often have conflicting views when setting CSR objectives [111]. This result supports the notation that larger board suffer from agency problem, slow decision process, and lack of harmony [112] and may not interested in CSR disclosures [113]. However, the coefficients of Ind_Dir and B_Share remain significant and positive in this study, which suggests that having independent directors on board and high board ownership affect companies' CSR investment positively. The results are consistent with previous literature; a large portion of an independent director or board share tend to be more socially responsible [109-111]. The results of economic variables such as Size and TobinQ 
remain significant and positive, supporting the notion that larger and more profitable firms invest more in CSR than others do [52,110,111]. The coefficients of F_Age and BTMA remain significantly negative, which indicates that younger and high growth opportunity corporates tend to do more CSR as compared to firms which are older and have fewer growth opportunities [24,102].

\section{Endogeneity}

Due to self-selection biases, the OLS results may be misleading, e.g., the characteristics of the corporation may vary based on high and low CSR performance. There can also be a case where CSR is different among firms due to their different characteristics, regardless of institutional contingencies. Firms with better CSRP and specific characteristics could be more likely to cross-list or move to the developed region, which could introduce selection bias in the study of SNIC-CSRP relationship and between the CSRP-CFP nexus. The relationship between the SNIC-CSRP and CSRP-CFP nexus may perhaps be driven by omitted variables of firm characteristics. To address these potential issues, this study follows the previous literature [82,100] and employs the propensity score matching (PSM) method. We estimate the propensity score using the probit model, where the dependent variable is SOE, cross-listing, and R_Dev, and the explanatory variables are all control variables used in this study. We then match each firm that is an SOE, is cross-listed, and is from a more developed region with its counterpart with the closest score, and conduct the regression analysis with the matched sample.

Table 7 depicts that the effect of SNICs (e.g., SOE vs. non-SOE, cross-listed vs. non-cross-listed, R_Dev vs. less-R_Dev) is significant and positive with CSRP. Thus, when focusing on firms that are non-SOEs, are non-cross-listed, and have less regional development with similar characteristics to firms that are SOEs, are cross-listed, and have more regional development, we find the latter remain significant and positive with regard to CSRP. Table 8 reports PSM results for the CSRP-CFP nexus. The results of all PSM models remain consistent with primary regression analysis.

Table 7. Robustness for subnational institutional contingencies and CSR performance.

\begin{tabular}{cccc}
\hline & \multicolumn{3}{c}{ PSM } \\
\hline CSR_Rating & Model 1 & Cross-Listed & R_Dev \\
\hline SOE & $0.38^{* * *}$ & - & Model 3 \\
& $(2.93)$ & & \\
Cross-listed & - & $7.96^{* * *}$ & \\
R_Dev & & $(6.04)$ & - \\
& - & - & $0.68^{* * *}$ \\
B_Size & -0.03 & $-0.26^{*}$ & $(2.62)$ \\
Ind_Dir & $(-0.48)$ & $(-1.61)$ & -0.01 \\
& 3.59 & -1.03 & $(-0.10)$ \\
CEO duality & $(1.31)$ & $(-0.18)$ & $(-0.14$ \\
& -0.50 & 0.63 & -0.54 \\
B_Share & $(-0.82)$ & $(0.60)$ & $(-1.35)$ \\
& $21.61^{* *}$ & 2.79 & 1.66 \\
Size & $(2.47)$ & $(0.95)$ & $(1.48)$ \\
& $152.25^{* * *}$ & $135.36^{* * *}$ & $129.52 * * *$ \\
Growth & $(40.85)$ & $(15.01)$ & $(37.40)$ \\
& 0.00 & -0.07 & 0.04 \\
F_Leverage & $(0.03)$ & $(-0.25)$ & $(0.35)$ \\
& $-2.18^{* * *}$ & $-7.58^{* * *}$ & $-2.71^{* * *}$ \\
& $(-7.47)$ & $(-5.49)$ & $(-8.18)$ \\
\hline
\end{tabular}


Table 7. Cont.

\begin{tabular}{cccc}
\hline & \multicolumn{3}{c}{ PSM } \\
\hline SOE & Cross-Listed & R_Dev \\
\hline CSR_Rating & Model 1 & Model 2 & Model 3 \\
\hline F_Age & 0.05 & -0.08 & $-0.17^{* * *}$ \\
& $(1.35)$ & $(-0.86)$ & $(-4.71)$ \\
TobinQ & $0.91^{* * *}$ & $0.15^{* * *}$ & $0.96^{* * *}$ \\
& $(9.18)$ & $(2.62)$ & $(9.29)$ \\
BTMA & $-1.96^{* * *}$ & $-1.55^{* * *}$ & $-1.22^{* * *}$ \\
& $(-8.94)$ & $(-3.19)$ & $(-4.89)$ \\
Constants & $-441.18^{* * *}$ & $-380.20^{* * *}$ & $-367.64^{* * *}$ \\
Year dummies & $(-38.75)$ & $(-13.38)$ & $(-34.52)$ \\
Industry dummies & Included & Included & Included \\
$\mathrm{R}^{2}$ & Included & Included & Included \\
& 0.273 & 0.378 & 0.276 \\
\hline
\end{tabular}

$* * * * * *$, significant at $10 \%, 5 \%$, and $1 \%$, respectively. $t$-statistics are reported in parentheses. For a detailed description of variables, see Table 1.

Table 8. Robustness for the moderating role of subnational institutional contingencies: nexus between CSR performance and financial performance.

\begin{tabular}{|c|c|c|c|c|c|c|}
\hline \multirow[b]{3}{*}{ Performance } & \multicolumn{6}{|c|}{ PSM } \\
\hline & \multirow{2}{*}{$\begin{array}{c}\text { SOE } \\
\text { Model } 1\end{array}$} & \multirow{2}{*}{$\begin{array}{c}\text { Non-SOE } \\
\text { Model } 2\end{array}$} & \multirow{2}{*}{$\begin{array}{c}\text { Cross-Listed } \\
\text { Model } 3\end{array}$} & \multicolumn{2}{|c|}{ Non-Cross-Listed R_Dev } & \multirow{2}{*}{$\begin{array}{c}\text { Less-R_Dev } \\
\text { Model } 6\end{array}$} \\
\hline & & & & Model 4 & Model 5 & \\
\hline CSR_Rating & $\begin{array}{l}0.03 * * \\
(2.65)\end{array}$ & $\begin{array}{c}0.02^{*} \\
(1.90)\end{array}$ & $\begin{array}{c}0.01^{*} \\
(1.64)\end{array}$ & $\begin{array}{c}0.04^{* * *} \\
(3.19)\end{array}$ & $\begin{array}{c}0.01 * * * \\
(6.92)\end{array}$ & $\begin{array}{c}0.00 * * * \\
(2.83)\end{array}$ \\
\hline SOE & - & - & $\begin{array}{l}-0.02 \\
(-0.14)\end{array}$ & $\begin{array}{l}-1.20^{*} \\
(-1.94)\end{array}$ & $\begin{array}{l}-0.20 * * \\
(-2.52)\end{array}$ & $\begin{array}{l}-0.12 * * * \\
(-2.67)\end{array}$ \\
\hline Cross-listed & $\begin{array}{l}0.65^{* *} \\
(2.61)\end{array}$ & $\begin{array}{l}0.25^{* *} \\
(1.98)\end{array}$ & 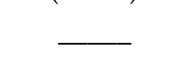 & - & $\begin{array}{c}0.61^{* * *} \\
(3.79)\end{array}$ & $\begin{array}{l}0.29 * * \\
(2.05)\end{array}$ \\
\hline R_Dev & $\begin{array}{c}0.15^{*} \\
(1.65)\end{array}$ & $\begin{array}{c}0.27 \\
(0.98)\end{array}$ & $\begin{array}{c}0.11 \\
(0.92)\end{array}$ & $\begin{array}{l}-0.29 \\
(-0.58)\end{array}$ & (10. & 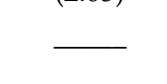 \\
\hline B_Size & $\begin{array}{c}0.03 \\
(1.54)\end{array}$ & $\begin{array}{l}0.01 \text { ** } \\
(2.22)\end{array}$ & $\begin{array}{c}0.02 \\
(1.37)\end{array}$ & $\begin{array}{c}-0.23^{* * *} \\
(-2.61)\end{array}$ & $\begin{array}{c}0.02 \\
(1.42)\end{array}$ & $\begin{array}{l}0.01 * * \\
(2.02)\end{array}$ \\
\hline Ind_Dir & $\begin{array}{c}0.89 \\
(1.53)\end{array}$ & $\begin{array}{l}-1.30 \\
(-0.49)\end{array}$ & $\begin{array}{c}0.79 \\
(1.33)\end{array}$ & $\begin{array}{l}-1.39 \\
(-0.46)\end{array}$ & $\begin{array}{c}0.69^{*} \\
(1.70)\end{array}$ & $\begin{array}{c}0.04 \\
(0.18)\end{array}$ \\
\hline CEO duality & $\begin{array}{c}0.14 \\
(0.85)\end{array}$ & $\begin{array}{l}-0.67 \\
(-1.39)\end{array}$ & $\begin{array}{c}0.12 \\
(0.81)\end{array}$ & $\begin{array}{l}-0.66 \\
(-1.29)\end{array}$ & $\begin{array}{c}0.13^{*} \\
(1.90)\end{array}$ & $\begin{array}{c}0.04 \\
(0.89)\end{array}$ \\
\hline B_Share & $\begin{array}{c}0.29 \\
(1.42)\end{array}$ & $\begin{array}{c}0.59 * * * \\
(3.11)\end{array}$ & $\begin{array}{c}-0.18 \\
(-0.19)\end{array}$ & $\begin{array}{c}-3.75^{* * * *} \\
(-2.69)\end{array}$ & $\begin{array}{c}0.19 \\
(1.02)\end{array}$ & $\begin{array}{l}0.59 * * * \\
(5.11)\end{array}$ \\
\hline Size & $\begin{array}{c}-10.62^{* * *} \\
(-16.12)\end{array}$ & $\begin{array}{l}-6.15^{* * *} \\
(-14.15)\end{array}$ & $\begin{array}{l}-5.61^{* * *} \\
(-6.92)\end{array}$ & $\begin{array}{c}-46.98^{* * *} \\
(-9.23)\end{array}$ & $\begin{array}{c}-11.82^{* * *} \\
(-20.10)\end{array}$ & $\begin{array}{l}-6.15^{* * *} \\
(-16.25)\end{array}$ \\
\hline Growth & $\begin{array}{l}0.19^{* *} \\
(2.27)\end{array}$ & $\begin{array}{c}0.12 \\
(1.29)\end{array}$ & $\begin{array}{l}0.17^{* *} \\
(2.37)\end{array}$ & $\begin{array}{l}0.140 \\
(1.09)\end{array}$ & $\begin{array}{c}-0.09 * * * \\
(-5.59)\end{array}$ & $\begin{array}{c}0.04^{* * *} \\
(3.55)\end{array}$ \\
\hline F_Leverage & $\begin{array}{l}1.10^{* * *} \\
(25.27)\end{array}$ & $\begin{array}{c}-1.17^{* * *} \\
(-8.23)\end{array}$ & $\begin{array}{l}-0.82^{* *} \\
(-2.31)\end{array}$ & $\begin{array}{c}1.85^{* * *} \\
(2.84)\end{array}$ & $\begin{array}{l}1.07^{* * *} \\
(27.37)\end{array}$ & $\begin{array}{l}-1.17^{* * *} \\
(-10.63)\end{array}$ \\
\hline F_Age & $\begin{array}{l}0.02^{*} \\
(1.69)\end{array}$ & $\begin{array}{c}0.15^{* * * *} \\
(2.90)\end{array}$ & $\begin{array}{c}0.02^{*} \\
(1.79)\end{array}$ & $\begin{array}{c}0.14^{* * * *} \\
(2.92)\end{array}$ & $\begin{array}{c}0.01^{*} \\
(1.77)\end{array}$ & $\begin{array}{c}0.01^{* * *} \\
(3.52)\end{array}$ \\
\hline BTMA & $\begin{array}{l}-0.65^{* * *} \\
(-12.46)\end{array}$ & $\begin{array}{l}-0.44^{* * *} \\
(-14.13)\end{array}$ & $\begin{array}{l}-0.10^{* *} \\
(-2.26)\end{array}$ & $\begin{array}{c}0.12 \\
(0.44)\end{array}$ & $\begin{array}{l}-0.56^{* * *} \\
(-13.86)\end{array}$ & $\begin{array}{l}-0.44^{* * *} \\
(-17.23)\end{array}$ \\
\hline Constants & $\begin{array}{c}35.65^{* * *} \\
(20.10)\end{array}$ & $\begin{array}{c}20.99^{* * * *} \\
(15.16)\end{array}$ & $\begin{array}{c}19.48^{* * * *} \\
(7.79)\end{array}$ & $\begin{array}{c}152.11^{* * *} \\
(9.60)\end{array}$ & $\begin{array}{c}37.68^{* * *} \\
(21.09)\end{array}$ & $\begin{array}{c}21.97^{* * * *} \\
(19.36)\end{array}$ \\
\hline Year Dummies & Included & Included & Included & Included & Included & Included \\
\hline $\begin{array}{l}\text { Industry Dummies } \\
\qquad \mathrm{R}^{2}\end{array}$ & Included & Included & Included & $\begin{array}{c}\text { Included } \\
0.107\end{array}$ & $\begin{array}{c}\text { Included } \\
0.381\end{array}$ & $\begin{array}{l}\text { Included } \\
0.503\end{array}$ \\
\hline
\end{tabular}

$*, *, * * *$, significant at $10 \%, 5 \%$, and $1 \%$, respectively. $t$-statistics are reported in parentheses. For a detailed description of variables, see Table 1 . 


\section{Conclusions}

Institutions play an imperative role in CSR; institutional theory suggests that companies prejudiced by pressure in their environment for conformity, compliance, and constraining organizational actions applied through their referent spectators. In particular, when companies design their CSR strategies and decide between different alternatives, they need to understand and balance various types of institutional logic that bring concurrent pressures, as companies must consider socially accepted rules [18-20]. The neo-institutional theory states that different organizations in various countries have different CSR priorities because of their cultural elements, e.g., organizational actions, legal rules, and beliefs [29].

The study endeavors to contribute by providing insights on the role of SNICs in CSRP and the relationship between CSRP and CFP. To explore these relationships, the study takes into account seven hypotheses by using recent data of all A-share companies listed on the Shenzhen, Shanghai, and Hong Kong stock exchanges. The findings suggest that CSRP and CFP have a positive and significant association, which means that if a firm performs well in CSRP, it will help to improve the CFP due to factors such as good corporate image and stakeholder trust. This study further endorses that CSRP is a legitimacy tool for better CFP. Second, there is empirical evidence that SNICs (e.g., SOE vs. non-SOE, cross-listed vs. non-cross-listed, R_Dev vs. less-R_Dev) have a positive association with CSRP. The results indicate that the companies located in developed regions or owned by the government or cross-listed on foreign stock exchange perform better in CSR due to factors such as media coverage, government pressure, sophisticated systems for securities supervision, the stringent regulations on CSR disclosure, information asymmetry, legal standards, and shareholder protection.

The moderating role of SNICs in shaping the relationship between CSRP and CFP is also explored. The empirical findings suggest that SNICs have a positive and significant role in the CSRP-CFP nexus. The moderating role of non-SOEs is more prominent and positive because SOEs are bound to do CSR by the government, while non-SOEs are involved in CSR based on resource constraints and care more about CFP. Likewise, the role of companies located in a less-developed region or non-cross-listed firms is more noticeable in the relationship between CSRP and CFP. It is advocated that regulators and individual companies enhance their financial performance (i.e., the primary objective of any firm) through investment in CSR. Moreover, the CSR can mitigate litigation risk and help against unfavorable regulation through a halo effect. The paper also has an important implication for China and other emerging economies with similar ownership characteristics and unbalanced regional development. Based on the combination of stakeholders' perspective and sub-national institutional contingencies, the study proposes a novel explanatory framework, which narrows the gap in understanding CSR drivers due to institutional variations.

From the perspective of practical implications, the study indicates that policymakers, executives, and managers should refrain from "one size fits it all" CSR policies. Instead, they need to evaluate the effects of regional development, cross-listing, and ownership characteristics at the same time. Considering weak social performance by firms in areas with less regional development, that are non-cross-listed, and that are non-SOEs, policymakers and the government should improve information transparency, provide stronger regulations, and give incentives for these firms to improve their CSRP. We also offer insights for other emerging economies, especially those going through extraordinary government interventions.

Although the research contributes to the literature, there are limitations that offer avenues for future research. The results somehow limit the generalizability of results because the study only focuses on the institutional environment of China, which is an emerging and transforming economy and differs in many aspects from developed countries. Therefore, future studies could test the same hypotheses in other developing and developed countries to enhance the generalizability of the findings. Moreover, all SNICs are from a single country only. Future studies can extend this study in multinational settings. One of the limitations is that it considers only one aspect of the company that is cross-listed or is located 
in areas with greater R_Dev. A future study could consider the combined effect of less-developed regions and cross-listed companies.

Author Contributions: Conceptualization, S.A.; formal analysis, S.A.; methodology, S.A., J.Z., M.U., F.U.K., A.I. and B.A.; writing—original draft, S.A.; writing-review and editing, S.A., J.Z., M.U., F.U.K., A.I. and B.A.

Funding: The authors acknowledge funding from National Natural Science Foundation of China (Grant Number 71472148) for this study.

Conflicts of Interest: The authors declare no conflict of interest.

\section{References}

1. Garde-Sanchez, R.; López-Pérez, M.V.; López-Hernández, A.M. Current Trends in Research on Social Responsibility in State-Owned Enterprises: A Review of the Literature from 2000 to 2017. Sustainability 2018, 10, 2403. [CrossRef]

2. Deegan, C.; Rankin, M.; Tobin, J. An examination of the corporate social and environmental disclosures of BHP from 1983-1997: A test of legitimacy theory. Account. Audit. Account. J. 2002, 15, 312-343. [CrossRef]

3. Chen, C.F.; Tsai, D. How destination image and evaluative factors affect behavioral intentions? Tour. Manag. 2007, 28, 1115-1122. [CrossRef]

4. Sial, M.S.; Zheng, C.; Khuong, N.V.; Khan, T.; Usman, M. Does Firm Performance Influence Corporate Social Responsibility Reporting of Chinese Listed Companies? Sustainability 2018, 10, 2217. [CrossRef]

5. Goranova, M.; Ryan, L.V. Shareholder Activism. J. Manag. 2013, 40, 1230-1268. [CrossRef]

6. Wu, C.L.; Fang, D.P.; Liao, P.C.; Xue, J.W.; Li, Y.; Wang, T. Perception of corporate social responsibility: The case of Chinese international contractors. J. Clean. Prod. 2015, 107, 185-194. [CrossRef]

7. Font, X.; Guix, M.; Bonilla-Priego, M.J. Corporate social responsibility in cruising: Using materiality analysis to create shared value. Tour. Manag. 2016, 53, 175-186. [CrossRef]

8. O'Rourke, A. A new politics of engagement: Shareholder activism for corporate social responsibility. Bus. Strat. Environ. 2003, 12, 227-239. [CrossRef]

9. Montiel, I. Corporate social responsibility and corporate sustainability-Separate pasts, common futures. Organ. Environ. 2008, 21, 245-269. [CrossRef]

10. Uhlaner, L.M.; Berent-Braun, M.M.; Jeurissen, R.J.M.; De Wit, G. Beyond Size: Predicting Engagement in Environmental Management Practices of Dutch SMEs. J. Bus. Ethics 2011, 109, 411-429. [CrossRef]

11. Hasan, I.; Kobeissi, N.; Liu, L.; Wang, H. Corporate Social Responsibility and Firm Financial Performance: The Mediating Role of Productivity. J. Bus. Ethics 2016, 149, 671-688. [CrossRef]

12. Fernández-Guadaño, J.; Sarria-Pedroza, J.H. Impact of Corporate Social Responsibility on Value Creation from a Stakeholder Perspective. Sustainability 2018, 10, 2062. [CrossRef]

13. Fassin, Y.; Werner, A.; Van Rossem, A.; Signori, S.; Garriga, E.; von Weltzien Hoivik, H.; Schlierer, H.J. CSR and related terms in SME owner-managers' mental models in six European countries: National context matters. J. Bus. Ethics 2015, 128, 433-456. [CrossRef]

14. Doh, J.P.; Guay, T.R. Corporate Social Responsibility, Public Policy, and NGO Activism in Europe and the United States: An Institutional-Stakeholder Perspective. J. Manag. Stud. 2006, 43, 47-73. [CrossRef]

15. Colombo, S.; Guerci, M.; Miandar, T. What Do Unions and Employers Negotiate Under the Umbrella of Corporate Social Responsibility? Comparative Evidence from the Italian Metal and Chemical Industries. J. Bus. Ethics 2017, 155, 445-462. [CrossRef]

16. Kang, N.; Moon, J. Institutional complementarity between corporate governance and Corporate Social Responsibility: A comparative institutional analysis of three capitalisms. Socio Econ. Rev. 2011, 10, 85-108. [CrossRef]

17. Marano, V.; Kostova, T. Unpacking the Institutional Complexity in Adoption of CSR Practices in Multinational Enterprises. J. Manag. Stud. 2016, 53, 28-54. [CrossRef]

18. Arena, M.; Azzone, G.; Mapelli, F. What drives the evolution of Corporate Social Responsibility strategies? An institutional logics perspective. J. Clean. Prod. 2018, 171, 345-355. [CrossRef]

19. Arena, M.; Azzone, G.; Mapelli, F. Corporate Social Responsibility strategies in the utilities sector:A comparative study. Sustain. Prod. Consum. 2019, 18, 83-95. [CrossRef] 
20. Mellahi, K.; Frynas, J.G.; Sun, P.; Siegel, D. A Review of the Nonmarket Strategy Literature. J. Manag. 2015, 42, 143-173. [CrossRef]

21. Frynas, J.G.; Yamahaki, C. Corporate Social Responsibility: An Outline of Key Concepts, Trends, and Theories. In Practising CSR in the Middle East; Palgrave Macmillan: Cham, Switzerland, 2019; pp. 11-37.

22. Jia, M.; Zhang, Z. The role of corporate donations in Chinese political markets. J. Bus. Ethics 2018, 153, 519-545. [CrossRef]

23. Marquis, C.; Qian, C. Corporate Social Responsibility Reporting in China: Symbol or Substance? Organ. Sci. 2014, 25, 127-148. [CrossRef]

24. Horak, S.; Restel, K. A Dynamic Typology of Informal Institutions: Learning from the Case of Guanxi. Manag. Organ. Rev. 2016, 12, 525-546. [CrossRef]

25. Du, J.; Bai, T.; Chen, S. Integrating corporate social and corporate political strategies: Performance implications and institutional contingencies in China. J. Bus. Res. 2019, 98, 299-316. [CrossRef]

26. Zhao, M. CSR-Based Political Legitimacy Strategy: Managing the State by Doing Good in China and Russia. J. Bus. Ethics 2012, 111, 439-460. [CrossRef]

27. Tang, P.; Yang, S.; Boehe, D. Ownership and corporate social performance in China: Why geographic remoteness matters. J. Clean. Prod. 2018, 197, 1284-1295. [CrossRef]

28. Ortas, E.; Álvarez, I.; Jaussaud, J.; Garayar, A.; Fredes, E.O. The impact of institutional and social context on corporate environmental, social and governance performance of companies committed to voluntary corporate social responsibility initiatives. J. Clean. Prod. 2015, 108, 673-684. [CrossRef]

29. Huang, X.X.; Hu, Z.-P.; Liu, C.S.; Yu, D.J.; Yu, L.F. The relationships between regulatory and customer pressure, green organizational responses, and green innovation performance. J. Clean. Prod. 2016, 112, 3423-3433. [CrossRef]

30. Giroud, X.; Mueller, H.M. Corporate Governance, Product Market Competition, and Equity Prices. J. Financ. 2011, 66, 563-600. [CrossRef]

31. Li, Z. Mutual monitoring and corporate governance. J. Bank. Financ. 2014, 45, 255-269.

32. Li, Z.F. Mutual Monitoring and Agency Problems. SSRN Electron. J. 2014. [CrossRef]

33. Coles, J.L.; Li, Z.; Wang, A.Y. Industry tournament incentives. Rev. Financ. Stud. 2017, 31, 1418-1459. [CrossRef]

34. Li, Z.F.; Lin, S.; Sun, S.; Tucker, A. Risk-adjusted inside debt. Glob. Financ. J. 2018, 35, 12-42. [CrossRef]

35. Core, J.; Guay, W. The use of equity grants to manage optimal equity incentive levels. J. Account. Econ. 1999, 28, 151-184. [CrossRef]

36. Sun, S.L.; Peng, M.W.; Shi, W.S.; Shi, W. Sub-National Institutional Contingencies, Network Positions, and IJV Partner Selection. J. Manag. Stud. 2012, 49, 1221-1245.

37. Khan, F.U.; Zhang, J.; Usman, M.; Badulescu, A.; Sial, M.S. Ownership Reduction in State-Owned Enterprises and Corporate Social Responsibility: Perspective from Secondary Privatization in China. Sustainability 2019, 11, 1008. [CrossRef]

38. Tse, E. The China Strategy: Harnessing the Power of the World's Fastest-Growing Economy; Basic Books: New York, NY, USA, 2010.

39. He, L.; Fang, J. Subnational institutional contingencies and executive pay dispersion. Asia Pac. J. Manag. 2015, 33, 371-410. [CrossRef]

40. Davis, G.F. New Directions in Corporate Governance. Annu. Rev. Sociol. 2005, 31, 143-162. [CrossRef]

41. North, D. Institutions, Institutional Change and Economic Performance; Cambridge University Press: Cambridge, MA, USA, 1990.

42. Scott, W.R. Institutions and Organizations; Sage Publications: Thousand Oak, CA, USA, 1995.

43. Mike, W.P.; Sunny, L.S.; Brian, P.; Hao, C.; Peng, M.W.; Sun, S.L.; Pinkham, B.; Chen, H. The Institution-Based View as a Third Leg for a Strategy Tripod. Acad. Manag. Perspect. 2009, 23, 63-81.

44. Westphal, J.D.; Gulati, R.; Shortell, S.M. Customization or Conformity? An Institutional and Network Perspective on the Content and Consequences of TQM Adoption. Adm. Sci. Q. 1997, 42, 366-394. [CrossRef]

45. Chen, D.; Li, S.; Xiao, J.Z.; Zou, H. The effect of government quality on corporate cash holdings. J. Corp. Financ. 2014, 27, 384-400. [CrossRef]

46. Xu, E.; Yang, H.; Quan, J.M.; Lu, Y. Organizational slack and corporate social performance: Empirical evidence from China's public firms. Asia Pac. J. Manag. 2015, 32, 181-198. [CrossRef] 
47. Filatotchev, I.; Nakajima, C. Corporate Governance, Responsible Managerial Behavior, and Corporate Social Responsibility: Organizational Efficiency Versus Organizational Legitimacy? Acad. Manag. Perspect. 2014, 28, 289-306. [CrossRef]

48. Moratis, L. Consequences of Collaborative Governance in CSR: An Empirical Illustration of Strategic Responses to Institutional Pluralism and Some Theoretical Implications. Bus. Soc. Rev. 2016, 121, 415-446. [CrossRef]

49. Bowen, H.R.; Johnson, F.E. Social Responsibilities of the Businessman, With a Commentary by Ernest Johnson, F.; University of Iowa Press: New York, NY, USA, 1953.

50. Li, Z.; Minor, D.; Wang, J.; Yu, C. A Learning Curve of the Market: Chasing Alpha of Socially Responsible Firms. SSRN Electron. J. 2019, 38. Available online: https://papers.ssrn.com/sol3/papers.cfm?abstract_id=3224796 (accessed on 15 September 2019). [CrossRef]

51. Lu, W.; Ye, M.; Chau, K.; Flanagan, R. The paradoxical nexus between corporate social responsibility and sustainable financial performance: Evidence from the international construction business. Corp. Soc. Responsib. Environ. Manag. 2018, 25, 844-852. [CrossRef]

52. McWilliams, A.; Siegel, D. Corporate Social Responsibility: A Theory of the Firm Perspective. Acad. Manag. Rev. 2001, 26, 117-127. [CrossRef]

53. Lundgren, T. A microeconomic model of corporate social responsibility. Metroeconomica 2011, 62, 69-95. [CrossRef]

54. Lee, J.; Graves, S.B.; Waddock, S. Doing good does not preclude doing well: Corporate responsibility and financial performance. Soc. Responsib. J. 2018, 14, 764-781. [CrossRef]

55. Barnett, M.L.; Salomon, R.M. Beyond dichotomy: The curvilinear relationship between social responsibility and financial performance. Strat. Manag. J. 2006, 27, 1101-1122. [CrossRef]

56. Simpson, W.G.; Kohers, T. The Link Between Corporate Social and Financial Performance: Evidence from the Banking Industry. J. Bus. Ethics 2002, 35, 97-109. [CrossRef]

57. Busch, T.; Friede, G. The Robustness of the Corporate Social and Financial Performance Relation: A Second-Order Meta-Analysis. Corp. Soc. Responsib. Environ. Manag. 2018, 25, 583-608. [CrossRef]

58. Aguilera, R.V.; Rupp, D.E.; Williams, C.A.; Ganapathi, J. Putting the S back in corporate social responsibility: A multilevel theory of social change in organizations. Acad. Manag. Rev. 2007, 32, 836-863. [CrossRef]

59. Story, J.; Neves, P. When corporate social responsibility (CSR) increases performance: Exploring the role of intrinsic and extrinsic CSR attribution. Bus. Ethics A Eur. Rev. 2015, 24, 111-124. [CrossRef]

60. Rettab, B.; Mellahi, K. Practising CSR in the Middle East; Springer: Berlin/Heidelberg, Germany, 2019.

61. Welford, R. Corporate social responsibility in Europe and Asia: Critical elements and best practice. J. Corp. Citizsh. 2004, 13, 31-47.

62. Khan, M.K.; He, Y.; Akram, U.; Sarwar, S. Financing and monitoring in an emerging economy: Can investment efficiency be increased? China Econ. Rev. 2017, 45, 62-77. [CrossRef]

63. Lazzarini, S.G. Strategizing by the government: Can industrial policy create firm-level competitive advantage? Strateg. Manag. J. 2015, 36, 97-112. [CrossRef]

64. Musacchio, A.; Lazzarini, S.G.; Aguilera, R.V. New Varieties of State Capitalism: Strategic and Governance Implications. Acad. Manag. Perspect. 2015, 29, 115-131. [CrossRef]

65. Fan, J.P.; Wong, T.; Zhang, T. Politically connected CEOs, corporate governance, and Post-IPO performance of China's newly partially privatized firms. J. Financ. Econ. 2007, 84, 330-357. [CrossRef]

66. Hu, F.; Pan, X.; Tian, G. Does CEO pay dispersion matter in an emerging market? Evidence from China's listed firms. Pac. Basin Financ. J. 2013, 24, 235-255. [CrossRef]

67. Firth, M.; Fung, P.M.; Rui, O.M. How ownership and corporate governance influence chief executive pay in China's listed firms. J. Bus. Res. 2007, 60, 776-785. [CrossRef]

68. Shen, W.; Lin, C. Firm Profitability, State Ownership, and Top Management Turnover at the Listed Firms in China: A Behavioral Perspective. Corp. Gov. Int. Rev. 2009, 17, 443-456. [CrossRef]

69. Campbell, J.L. Why would corporations behave in socially responsible ways? an institutional theory of corporate social responsibility. Acad. Manag. Rev. 2007, 32, 946-967. [CrossRef]

70. Hung, M.Y.; Wong, T.; Zhang, T. Political considerations in the decision of Chinese SOEs to list in Hong Kong. J. Account. Econ. 2012, 53, 435-449. [CrossRef]

71. Li, D.; Lin, H.; Yang, Y.-W. Does the stakeholders-Corporate social responsibility (CSR) relationship exist in emerging countries? Evidence from China. Soc. Responsib. J. 2016, 12, 147-166. [CrossRef] 
72. Zheng, H.; Zhang, Y. Do SOEs outperform private enterprises in CSR? Evidence from China. Chin. Manag. Stud. 2016, 10, 435-457. [CrossRef]

73. Li, S.; Song, X.; Wu, H. Political Connection, Ownership Structure, and Corporate Philanthropy in China: A Strategic-Political Perspective. J. Bus. Ethics 2014, 129, 399-411. [CrossRef]

74. Zhang, C. Political connections and corporate environmental responsibility: Adopting or escaping? Energy Econ. 2017, 68, 539-547. [CrossRef]

75. Chen, J.; Ezzamel, M.; Cai, Z. Managerial power theory, tournament theory, and executive pay in China. J. Corp. Financ. 2011, 17, 1176-1199. [CrossRef]

76. Liu, X.; Zhang, C. Corporate governance, social responsibility information disclosure, and enterprise value in China. J. Clean. Prod. 2017, 142, 1075-1084. [CrossRef]

77. Smith, N.; Smith, V.; Verner, M. Do women in top management affect firm performance? A panel study of 2,500 Danish firms. Int. J. Prod. Perform. Manag. 2006, 55, 569-593. [CrossRef]

78. Li, Q.; Luo, W.; Wang, Y.; Wu, L. Firm performance, corporate ownership, and corporate social responsibility disclosure in China. Bus. Ethics A Eur. Rev. 2013, 22, 159-173. [CrossRef]

79. Shi, H.; Zhang, X.; Zhou, J. Cross-listing and CSR performance: Evidence from AH shares. Front. Bus. Res. China 2018, 12, 11. [CrossRef]

80. Ferris, S.P.; Kim, K.A.; Noronha, G. The Effect of Crosslisting on Corporate Governance: A Review of the International Evidence. Corp. Gov. Int. Rev. 2009, 17, 338-352. [CrossRef]

81. Boubakri, N.; El Ghoul, S.; Wang, H.; Guedhami, O.; Kwok, C.C. Cross-listing and corporate social responsibility. J. Corp. Financ. 2016, 41, 123-138. [CrossRef]

82. Bell, R.G.; Filatotchev, I.; A Rasheed, A. The liability of foreignness in capital markets: Sources and remedies. J. Int. Bus. Stud. 2011, 43, 107-122. [CrossRef]

83. Liu, G. Do Cross-Listed Firms Report Better Social Responsibility Performance? In Proceedings of the SHS Web of Conferences, Kuching Sarawak, Malaysia, 14 February 2017. 05003.

84. Koh, P.S.; Qian, C.; Wang, H. Firm litigation risk and the insurance value of corporate social performance. Strateg. Manag. J. 2014, 35, 1464-1482. [CrossRef]

85. Hong, H.; Liskovich, I. Crime, Punishment and the Halo Effect of Corporate Social Responsibility; National Bureau of Economic Research: Cambridge, MA, USA, 2015.

86. Sun, Q.; Tong, W.H.; Wu, Y. Overseas listing as a policy tool: Evidence from China's H-shares. J. Bank. Financ. 2013, 37, 1460-1474. [CrossRef]

87. Del Mar Miras-Rodríguez, M.; Carrasco-Gallego, A.; Escobar-Pérez, B. Are socially responsible behaviors paid off equally? A cross-cultural analysis. Corp. Soc. Responsib. Environ. Manag. 2015, 22, 237-256. [CrossRef]

88. Chan, C.M.; Makino, S.; Isobe, T. Does subnational region matter? Foreign affiliate performance in the United states and China. Strat. Manag. J. 2010, 31, 1226-1243. [CrossRef]

89. Fan, G.; Wang, X.; Zhu, H. NERI Index of Marketization of China's Provinces 2011 Report; Economic Science Press: Beijing, China, 2011.

90. Cordeiro, J.J.; He, L.; Conyon, M.; Shaw, T.S. Informativeness of performance measures and Chinese executive compensation. Asia Pac. J. Manag. 2013, 30, 1031-1058. [CrossRef]

91. Marquis, C.; Glynn, M.A.; Davis, G.F. Community isomorphism and corporate social action. Acad. Manag. Rev. 2007, 32, 925-945. [CrossRef]

92. Davis, J.C.; Henderson, J.V. The agglomeration of headquarters. Reg. Sci. Urban Econ. 2008, 38, 445-460. [CrossRef]

93. Husted, B.W.; Jamali, D.; Saffar, W. Near and dear? The role of location in CSR engagement. Strateg. Manag. J. 2016, 37, 2050-2070. [CrossRef]

94. Klier, T.; Testa, W. Location trends of large company headquarters during the 1990s. Econ. Perspect. -Fed. Reserve Bank Chic. 2002, 26, 12-26.

95. Conyon, M.J.; He, L. CEO turnover in China: The role of market-based and accounting performance measures. Eur. J. Financ. 2014, 20, 657-680. [CrossRef]

96. Bebchuk, L.A.; Cremers, K.M.; Peyer, U.C. The CEO pay slice. J. Financ. Econ. 2011, 102, 199-221. [CrossRef]

97. Barnea, A.; Rubin, A. Corporate Social Responsibility as a Conflict Between Shareholders. J. Bus. Ethics 2010, 97, 71-86. [CrossRef] 
98. Wu, W.F.; Johan, S.A.; Rui, O.M. Institutional Investors, Political Connections, and the Incidence of Regulatory Enforcement Against Corporate Fraud. J. Bus. Ethics 2016, 134, 709-726. [CrossRef]

99. Hung, M.; Shi, J.; Wang, Y. Mandatory CSR Disclosure and Information Asymmetry: Evidence from a Quasi-natural Experiment in China. In Proceedings of the Asian Finance Conference 2013. Available online: https://papers.ssrn.com/sol3/papers.cfm?abstract_id=2206877 (accessed on 15 September 2019). [CrossRef]

100. McGuinness, P.B.; Vieito, J.P.; Wang, M. The role of board gender and foreign ownership in the CSR performance of Chinese listed firms. J. Corp. Financ. 2017, 42, 75-99. [CrossRef]

101. Luo, X.; Wang, D.; Zhang, J. Whose Call to Answer: Institutional Complexity and Firms' CSR Reporting. Acad. Manag. J. 2017, 60, 321-344. [CrossRef]

102. Lau, C.M.; Lu, Y.; Liang, Q. Corporate Social Responsibility in China: A Corporate Governance Approach. J. Bus. Ethics 2016, 136, 73-87. [CrossRef]

103. Harjoto, M.A.; Jo, H. Corporate Governance and CSR Nexus. J. Bus. Ethics 2011, 100, 45-67. [CrossRef]

104. Borghesi, R.; Houston, J.F.; Naranjo, A. What Motivates Corporate Managers to Make Socially Responsible Investments? SSRN Electron. J. 2012, 26, 164-181. [CrossRef]

105. Jiraporn, P.; Chintrakarn, P. How do powerful CEOs view corporate social responsibility (CSR)? An empirical note. Econ. Lett. 2013, 119, 344-347. [CrossRef]

106. Li, F.; Li, T.; Minor, D. CEO power, corporate social responsibility, and firm value: A test of agency theory. Int. J. Manag. Financ. 2016, 12, 611-628. [CrossRef]

107. McCarthy, S.; Oliver, B.; Song, S. Corporate social responsibility and CEO confidence. J. Bank. Financ. 2017, 75, 280-291. [CrossRef]

108. Cai, Y.; Jo, H.; Pan, C. Vice or Virtue? The Impact of Corporate Social Responsibility on Executive Compensation. J. Bus. Ethics 2011, 104, 159-173. [CrossRef]

109. Fernández-Gago, R.; Cabeza-García, L.; Nieto, M. Independent directors' background and CSR disclosure. Corp. Soc. Responsib. Environ. Manag. 2018, 25, 991-1001. [CrossRef]

110. Yu, L.; Wang, D.; Wang, Q. The Effect of Independent Director Reputation Incentives on Corporate Social Responsibility: Evidence from China. Sustainability 2018, 10, 3302. [CrossRef]

111. García-Sánchez, I.M.; Cuadrado-Ballesteros, B.; Sepulveda, C. Does media pressure moderate CSR disclosures by external directors? Manag. Decis. 2014, 52, 1014-1045. [CrossRef]

112. Rao, K.K.; Tilt, C.A.; Lester, L.H. Corporate governance and environmental reporting: An Australian study. Corp. Gov. Int. J. Bus. Soc. 2012, 12, 143-163.

113. Esa, E.; Ghazali, N.A.M. Corporate social responsibility and corporate governance in Malaysian government-linked companies. Corp. Gov. Int. J. Bus. Soc. 2012, 12, 292-305. [CrossRef] 